\title{
Society 5.0 in Education: Higher Order Thinking Skills
}

\author{
Prima Mytra ${ }^{1 *}$, Wardawaty $^{2}, \mathrm{Akmal}^{3}, \mathrm{Kusnadi}^{4}, \mathrm{Rahmatullah}^{5}$ \\ \{mytraprima@gmail.com ${ }^{1}$ \} \\ Institut Agama Islam Muhammadiyah Sinjai, Indonesia ${ }^{1,3,4,5}$ \\ Universitas Negeri Makassar, Indonesia ${ }^{2}$
}

\begin{abstract}
The social life, even in education, is increasingly changing with technological innovation that is growing rapidly. A new idea, the society 5.0, was presented in 2016 to anticipate the technological developments. It becomes one of the Japanese government's efforts in dealing with global trends that emerged due to sector and society. The purpose of the research is to describe how the students prepare to face society 5.0 with a focused review of some research about it and high order thinking. The method used is the study of literature while the source data are from secondary data. Data collection methods apply textbooks, journals, and research studies. The result of the study reveals that the presence of society 5.0 will be able to solve social problems through a global system integrated from virtual and real space. Especially in the world of education, students must have a high level of thinking ability, such as, the ability to solve problems, think critically, and be creative. These are parts of higher-order thinking skills, and they will help the students to solve each problem faced within school and community.
\end{abstract}

Keywords: Higher-order thinking skills, technology, society of 5.0

\section{Introduction}

The development of IT and technology demand 4.0 for society 5.0, which the Japanese government has created with the concept of a human-centered society and technology, requires education in order to revolutionize distance learning [1]. Different ideas have been developed to replace traditional methods of learning, one of which is e-learning. It can be used as an alternative to educational problems, complementing and replacing existing learning activities [2].

Society 5.0 essentially uses artificial intelligence, the Internet of Things (IoT), machine learning and big data [1]. The emergence of it is able to solve social problems through integrated digital systems from virtual and real space [3]. From the practice of society 4.0 to society 5.0 in the community, we are required to have Higher Order Thinking Skills (HOTS). Similarly, in the world of education, Higher Order of Thinking Skills (HOTS) is integrated with character education so that students' higher thinking skills and creativity do not override the local wisdom of each region.

This new era becomes a challenge and opportunity for society and students specially to improve their soft skills in order to increase the learning proficiency and skills to be the capital of the future. Therefore, it has need of a High Order of Thinking Skills (HOTS) learning system implementation.

In the world of education students must have three high-level skills: problem-solving skills, critical thinking, and social creativity [4]. These three abilities are achieved by the higher order 
of thinking skills (HOTS). HOTS is an over-average cognitive thinking developed from different cognitive concepts and methods, as well as learning taxonomy, where students are required to treat information and ideas without changing meaning and impact.

These changes are made when students combine facts and ideas to synthesize, explain, assumed or arrive at conclusions or interpretations that are part of the problem-solving, taxonomic flourishing, taxonomy learning, teaching, and evaluation method [5]. According to the floral taxonomy and taxonomic learning, students can solve problems and find new meanings (for them). Teachers' role in realizing students' high thinking abilities is to create activities or environments by engaging students in high-level thinking as knowledge producers without forgetting moral education and character.

\section{Method}

This research uses a literature study. The data used is secondary data. The author will collect relevant data or information and examine various theories and reference sources both the research results, such as books, journals, articles, and other authors' relevant thoughts about society 5.0 and higher-order thinking skills. The data sources we obtain from journals, previous research, and news will be analyzed by providing narration descriptions to explain the research results. A literature study carried out the analysis data. The literature study was carried out with reading library sources to obtain the required data. Collect seeds of study material relevant to the research problem, quote information, conclude, and interpret the results.

\section{Result and Discussion}

\subsection{Presenting the results}

\subsubsection{Society 5.0}

Company 5.0 is Japan's vision to anticipate the 4.0 industrial revolution. Sociéte 5.0 is a super intelligent society that integrates technologies such as artificial intelligence (AI), the Internet of Things (IoT), big data and robots into every social lifeline [6]. Specifically, society 5.0 aims to build an intelligent society by creating a "super intelligent social services platform" that will create new values by cooperating and cooperating with several different systems to facilitate human work [2].

Society 5.0 is the basic plan of the fifth technology and science as a future society, which is Japan's vision to be built on society 4.0 and aims for society [8]. At first, the society was formulated from the society of hunting (society 1.0), the society of agriculture (Society 2.0), the society of industrial (Society 3.0), and the society of information (Society4.0) [9]. Changes in human habits from time to time can be seen in Figure 1 below: 


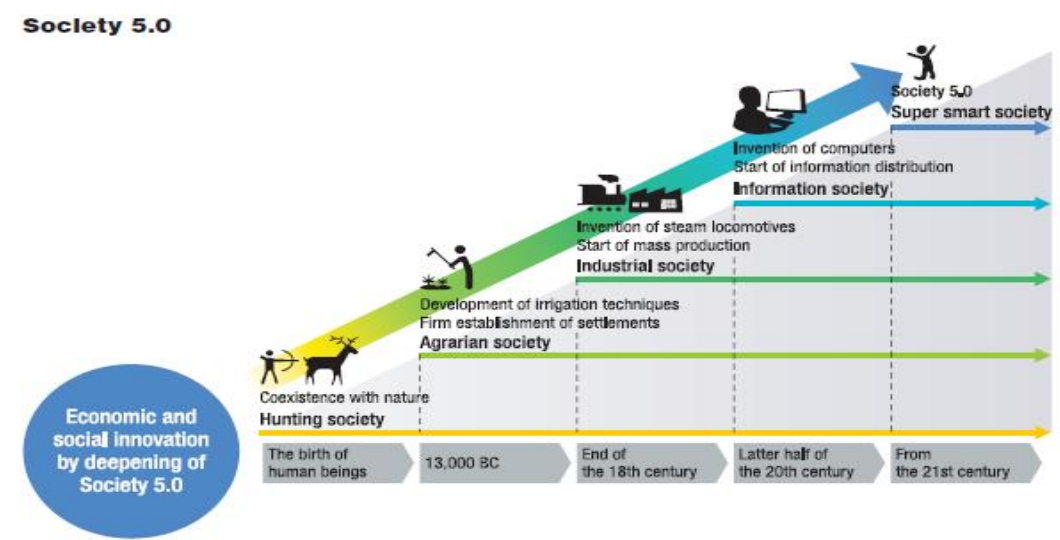

Fig. 1. Era Development from 1.0 to $5.0[3]$

Figure 1 shows that the differences in human life habits from each era. Every age, there is an increase in humans' technology from a learning and human way of thinking [2].

With the concept of society 5.0, Japan introduced digital technology for various systems and accelerated its implementation to dynamically achieve a society where all citizens are involved. The Japanese government wants to build a society in which all citizens, including young and elderly people, women and men, disabilities and disabled people with intractable diseases, can live a satisfying life and demonstrate their full ability, that is to say, to a society in which all citizens participate dynamically. The system revolution will be innovated by Internet of Things, Big Data, Robots and Artificial Intelligence on automated driving, health care, financial transactions, construction, agriculture, forestry, and fishing and tourism [3].

The use of the Internet of Things (IoT) in education changes the traditional teaching practices and brings about changes to educational institutions' infrastructure. Internet of Things (IoT) is one of the four things that make universities produce qualified graduates, namely competency-based education, the use of IoT (Internet of Things), using virtual or augmented reality, and the utilization of AI (Artificial Intelligence) [4].

The Internet plays very important role to facilitate the learning for cognitive enhancement of students in formal and informal environments. To improve their intellectuals, online course and internet media are necessary to provide [5].

\subsubsection{Higher order thinking skills (HOTS)}

Lessons that require higher thinking skills for specific communication clarity as well as reducing ambiguity and confusion and improving students' thinking processes. The learning plan should include learning models that enhance student thinking, such as applied thinking, and adaptation to various student needs. Scaffolding (supporting students at the start of lessons and allowing students to study independently) helps students to develop their skills in learning [7].

Education is very useful in the era of society 5.0, which is formed by the results or products of the 4.0 industrial revolution. Education is a major factor in efforts to improve the quality of human resources. In line with one of the goals of national education is to realize a creative human being. Therefore, varieties of learning methods and models arise to improve high-order thinking skills (HOTS) [8]. 
Thinking at a high level encompasses critical thinking, problem solving, and reasoning. Bloom (1956) first presented the term "taxonomy bloom" as a high level thinking or commonly referred to as Higher Order Thinking Skippers (HOTS) in his book Taxonomy of Educational Objectives: Classification of Educational Targets. Bloom argues that there are three important domains to understand the purpose of learning, namely; cognitive, affective, and psychomotor [9]. There are six thought processes in theory Bloom, they are; 1) knowledge; 2) comprehension; 3) application; 4) synthesis; 5) evaluation. Then in 2001, the Bloom version of the cognitive domain was revised by Lorin Andreson, David Karthwhol, et al to become; 1) recollection; 2) comprehension; 3) application; 4) analysis; 5) evaluation; 6) creation [10]. The following is shown in the matric Figure 2 of the revision made by Lorin Andreson:

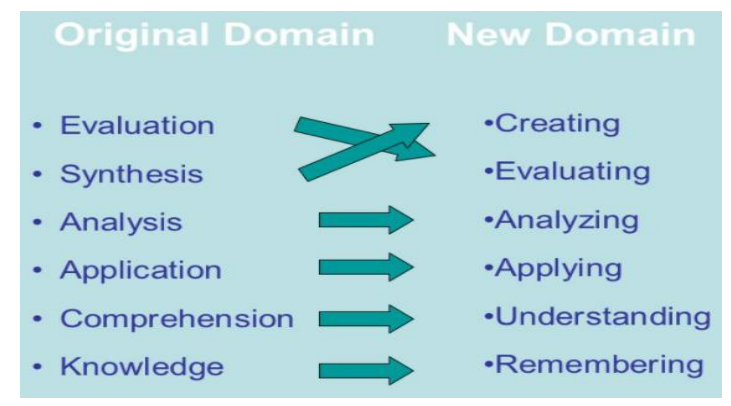

Fig. 2. Mapping revision taxonomy bloom [10]

Figure 2 shows that Lorin Anderson made a cognitive domain change that Bloom had compiled. Matrix changes are expected to make each individual able to reach the hots level. Various types of learning models that experts have put forward can be used to improve students' problem solving, critical thinking, and creative skills. So "HOTS can be said to succeed if students are involved with what they know in the learning process then students are able to distinguish thoughts or ideas clearly, argue well, be able to solve problems, be able to construct explanations, be able to hypothesize and understand complex things clearer, where this ability extremely shows how students reason"[11]

\subsubsection{Higher order thinking skills (HOTS) implementation and strategies}

Lessons that require a high level of thinking skills instruct technical communication to reduce student confusion and improve students' thinking abilities. Learning plans should be designed using models to improve learning skills, examples of applied thinking and adaptation of the needs of every student. Teachers help students gradually to learn and require students to learn independently to help students develop high-level learning skills. Good learning strategies have stages of training, organization, elaboration, and metacognition. Lessons should be specifically designed to teach specific learning strategies. Each Teacher is advised to reduce direct learning or teacher-centered learning and prioritize practical knowledge [3].

The importance of providing effective hots learning to achieve the vision and mission of the educational objectives is on teachers' shoulders to prepare learning that can realize students with HOTS abilities and can transmit information into secondary, constructive, and understand the meaning of learning. 


\subsection{Discussion}

The results of the study literature found some relationship between society 5.0 and higherorder thinking. Hayashi et al., revealed that society 5.0 would solve social problems through a global system integrated from virtual and real space [2]. The use of the internet, software, and robots is part of technologies emerging today that are parts of society 5.0. According to society 5.0, especially in education, students must have a high level of thinking ability. As L. Goodson points out the three higher-order thinking abilities are the ability to solve problems, think critically, and creativity [7]. Besides having a high level of thinking ability, it should also be aligned with character education so it is not easy to forget and does not rule out each region's local wisdom. The use of visual media as part of the use of the software is always interesting to apply in education. Smith and Lazo's (2014) research one of them on Developing thinking skills through the visual: an a / $\mathrm{r}$ / topographical journey, where this research emphasizes 'thinking' as the main competency and emphasizes visual literacy development. This study showed that students' critical thinking skills could be developed through visuals [12]. According to the use of software, the use of the Internet of Things (IoT) also affects students' thinking skills. Zin's research explains this, Rosli, Saleh (2019) in the Effectiveness of online learning environment in improving thinking skills in mathematics, which found that students who learned using online learning could also enhance students' thinking skills [13]. Hence, in this case, increasing thinking skills by using an online learning environment is possible.

From some study literature, it requires preparation done to welcome the presence of 5.0 to dominate the era in the future. Similarly, in education, everyone must prepare carefully in the face of the challenges of society 5.0 because education is the main factor in efforts to improve the quality of human resources. This proves that it is necessary to have the establishment of High Order Thinking Skills to answer the challenges of society 5.0.

\section{Conclusion}

Technology today demands the education to evolve into an E-learning method, especially in the face of the Era Society 5.0 that Japan's government has initiated. In order to respond to the challenges of society 5.0 and to achieve educational goals, students must prepare for higher order thought skills (HOTS). Higher Order Thinking Skills is one of the important competencies in the era of society 5.0. Hence, teachers must improve soft skills to enhance their competence and skills with the High Order Thinking Skills learning system, especially students.

\section{Acknowledgements}

Deep thanks to all those who helped this article written, especially to the beloved campus that has been encouraged by facilitating funding to support this article's publication at the Borobudur International Symposium Conference held by the University of Muhammadiyah Malang. We do Not forget to thank to co-authors for their ideas and concept in writing this article. Hopefully, this article is acceptable and useful to the community, especially in the field of education. 


\section{References}

[1] K. Grunwitz, "The future is Society 5.0," Computer Fraud \& Security, vol. 2019, no. 8, p. 20, Aug. 2019, DOI: 10.1016/S1361-3723(19)30087-9.

[2] H. Hayashi, H. Sasajima, Y. Takayanagi, and H. Kanamaru, "International standardization for smarter society in the field of measurement, control and automation," in 2017 56th Annual Conference of the Society of Instrument and Control Engineers of Japan (SICE), Kanazawa, Sep. 2017, pp. 263-266, DOI: 10.23919/SICE.2017.8105723.

[3] M. Fukuyama, "Society 5.0: Aiming for a New Human-Centered Society," p. 4.

[4] F. E. Nastiti and A. R. Ni'mal, "Kesiapan Pendidikan Indonesia Menghadapi era society 5.0," p. 6.

[5] H. Park and P. Shea, "A Review of Ten-Year Research through Co-citation Analysis: Online Learning, Distance Learning, and Blended Learning," Online Learning, vol. 24, no. 2, p. 20, 2020.

[6] S. Abe, "How students are being prepared for Society 5.0," 2016, [Online]. Available: https://www.globaljapan.wor ld/article/japan-leads-world-ineducation-for-society-5-0/.

[7] L. Goodson, "HIGHER ORDER THINKING SKILLS:," p. 177.

[8] S. Alam, "Higher Order Thinking Skills (HOTS): Kemampuan Memecahkan Masalah, Berpikir Kritis dan Kreatif dalam Pendidikan Seni untuk Menghadapi Revolusi Industri 4.0 pada Era Society 5.0," p. 9 .

[9] B. S. Bloom, M. D. Engelhart, E. J. Furst, W. H. Hill, and D. R. Krathwohl, TAXONOMY OF EDUCATIONAL OBJECTIVES The Classification of Educational Goals, vol. 1, 1-201 vols. SIMULTANEOUSLY IN THE DOMINION OF CANADA, 1956.

[10] D. Clark, "Bloom's Taxonomy of Learning Domains," 2015. http://www.nwlink.com/ donclark/hrd/bloom.html.

[11] R. P. Wibawa and D. R. Agustina, "PERAN PENDIDIKAN BERBASIS HIGHER ORDER THINKING SKILLS (HOTS) PADA TINGKAT SEKOLAH MENENGAH PERTAMA DI ERA SOCIETY 5.0 SEBAGAI PENENTU KEMAJUAN BANGSA INDONESIA," p. 5.

[12] V. G. Lazo and J. Smith, "Developing thinking skills through the visual: An a/r/tographical journey," International Journal of Education Through Art, vol. 10, no. 1, pp. 99-116, Mar. 2014, DOI: 10.1386/eta.10.1.99_1.

[13] A. F. M. Zin, M. S. Rosli, and N. S. Saleh, "Effectiveness of online learning environment in improving thinking skill in mathematics," Kedah, Malaysia, 2019, p. 050039, DOI: 10.1063/1.5121144. 